\title{
Revision of the Sakakieto-Cyclobalanopsidetum stenophyllae and Related Associations in Japan
}

\author{
by Takayuki Suganuma*
}

Received December 24, 1964

\section{Introduction}

About ten years have passed by, since $T$. Suzuki ${ }^{1,2}$ reported the outline of the Shiion sieboldii, warm-temperate forest climax in Japan. The alliance is composed of a number of associations, but four groups, namely Machilus-, Shiia-, Cyclobalanopsis-, and Maqui-types, are detectable not only from floristic composition, but also in ecological and physiognomical points of view. The third group, Cyclobalanopsis-type forest implies the following five associations.

1. Sakakieto-Cyclobalanopsidetum stenophyllae Suz.-Tok. $1952^{1 /}$

distributed in Pacific side of Honshu (southwestward from the southern region of Miyagi Prefecture), Shikoku and the mountain region of Kyushu.

2. Illicieto-Distylietum racemosae Suz.-Tok. $1951^{3)}$

distributed in the southern region of Kyushu.

3. Aucubeto-Cyclobalanopsidetum stenophyllae Sasaki 19584)

distributed in the Japan Sea side of Western Honshu.

4. Nandineto-Cyclobalanopsidetum glaucae Yamanaka $1955^{5)}$

distributed in Shikoku.

5. Skimmieto-Cyclobalanopsidetum acutae Sumata et al. 1956

distributed in the mountain region of Kyushu.

6. Cyclobalanopsis gilva-Bestand Suz.-Tok. $1960^{7}$ (not yet authorized by the table)

distributed in Mie Prefecture and Kyushu.

For the first step, this revision concerns with the first and the fifth associations. The second and the third stand near to the Sakakieto-Cyclobalanopsidetum stenophyllae, but field data are now being accumulated in Southern Kyushu and the Yaku Island. The time has come, however, to make the revision of the Sakakieto-Cyclobalanopsidetum stenophyllae by one comprehensive table.

In spite of the difference in the methodology, the Sakakieto-Cyclobalanopsidetum stenophyllae proved to be a good vegetational unit in the broad-leaved evergreen forest in Japan. It would be a good suballiance under the Shiion sieboldii and three distinct associations are recognized by the unified table.

\section{Historicals}

As early as in 1900, S. Honda ${ }^{8}$ established the zone of evergreen oak as the subtropical forest of Japan. This zone coincides with the zone of black pine, formerly proposed by $Z$. Tanaka ${ }^{9}$. It is a noticeable achievement of the Japanese forest botanist that he could denominate a forest zone after a climax tree instead of an aspect-determining pine species induced by human disturbances. The subtropical forest Honda describes, however, must be called as the warm-temperate forest

* Department of Botany, Faculty of Science, Nara Women's University, Nara, Japan. 
from the modern ecological viewpoint ${ }^{10)}$.

Nakano ${ }^{11}$ was the first, who studied phytosociologically the Cyclobalanopsis-type forest in our country. In 1943, he investigated the forest at Mt. Kiyozumi in the Boso Peninsula and named it the Machileto-Shiietum sieboldi-Quercetosum stenophyllae, but to our regret this association is not authorized by the table.

After the World War II, T. Suzuki and his collaborators started the phytosociological study of the Japanese evergreen forests. The Sakakieto-Cyclobalanopsidetum stenophyllae was authorized by two summarized association tables from the Boso and the Izu Peninsulas ${ }^{12,13)}$. The original Latin name for the association, Cyclobalanopsidetum sakakiosum stenophyllae was not proper for an association to be abandoned by the author himself (after the advice of J. Braun-Blanquet by the letter), and it must be amended as Sakakieto-Cyclobalanopsidetum stenophyllae ${ }^{1,14}$ after the original Japanese and English name. This association was enlarged later to the Tokai District by T. Suzuki ${ }^{15)}$, to the southwestern part of Shikoku by Nomoto ${ }^{16)}$, to the San'in District by T. Suzuki ${ }^{17)}$, to the Sandankyo Gorge of Hiroshima Prefecture by Horikawa and Sasaki ${ }^{18)}$, to the central part of Kyushu by T. Suzuki ${ }^{6,19)}$, to the whole Shikoku by Yamanaka ${ }^{20)}$ and to the central part of the Kii Peninsula also by Suganuma ${ }^{21}$.

Suzuki and Hatiya ${ }^{13)}$ established two subassociations in the Izu Peninsula, and Nomoto ${ }^{16)}$ enlarged one of them tsugetosum to Shikoku, and added one more, distylietosum in Shikoku. The subassociation distylietosum was later enlarged by $\mathrm{T}$. Suzuki ${ }^{6,19}$ to Kyushu. And Yamanaka ${ }^{20)}$ distinguished the subassociation rhodoretosum to the upper part of this association in Shikoku, and Suganuma ${ }^{21}$ established the subassociation osmanthetosum from the earlier writer's unified table in Pacific side of Honshu and a part of Shikoku.

Now the Sakakieto-Cyclobalanopsidetum is known from the largest area of Central and Southwestern Japan.

The Skimmieto-Cyclobalanopsidetum acutae Sumata et al. was orally published in $1956^{22)}$ and was authorized by the table in $1964^{6}$. It is an evergreen broad-leaved forest of mossy forest-type, and the Aucubeto-Cyclobalanopsidetum stenophyllae Sasaki $^{4}$ was reported from Mt. Mitoku of Tottori Prefecture by Sasaki in 1958, it is an association of the Japan Sea type.

The Illicieto-Distylietum racemosae reported with the table from the Oosumi Peninsula was later enlarged by Usui and Kasiwa ${ }^{23)}$ to the Island of Yaku. It is a vicariant association in Southern Japan with the Sakakieto-Cyclobalanopsidetum. The relationship between these two associations is surely interesting, but the field survey of the Illicieto-Distylietum racemosae in Mt. Kirishima and the Island of Yaku is not come to an end, so that the writer preserved this project until the coming chance.

\section{Methodology}

Before his visit to Europe in 1962, T. Suzuki ${ }^{24)}$ laid more weight on the dominance to determine the diagnostic value of species. As mentioned above, there were some differences in defining the character species of the association rank between the methods of European phytosociologists and those of Japanese researchers. Before the personal contact with European phytosociologists after World War II the criteria proposed by Szafer and Powlowski cited in the Braun-Blanquet's "Pflanzensoziologie" was the only base to find out the character species in Japan, and it is natural more 
Table 1. A unified table of the suballiance Sakakio-Cyclopsidion

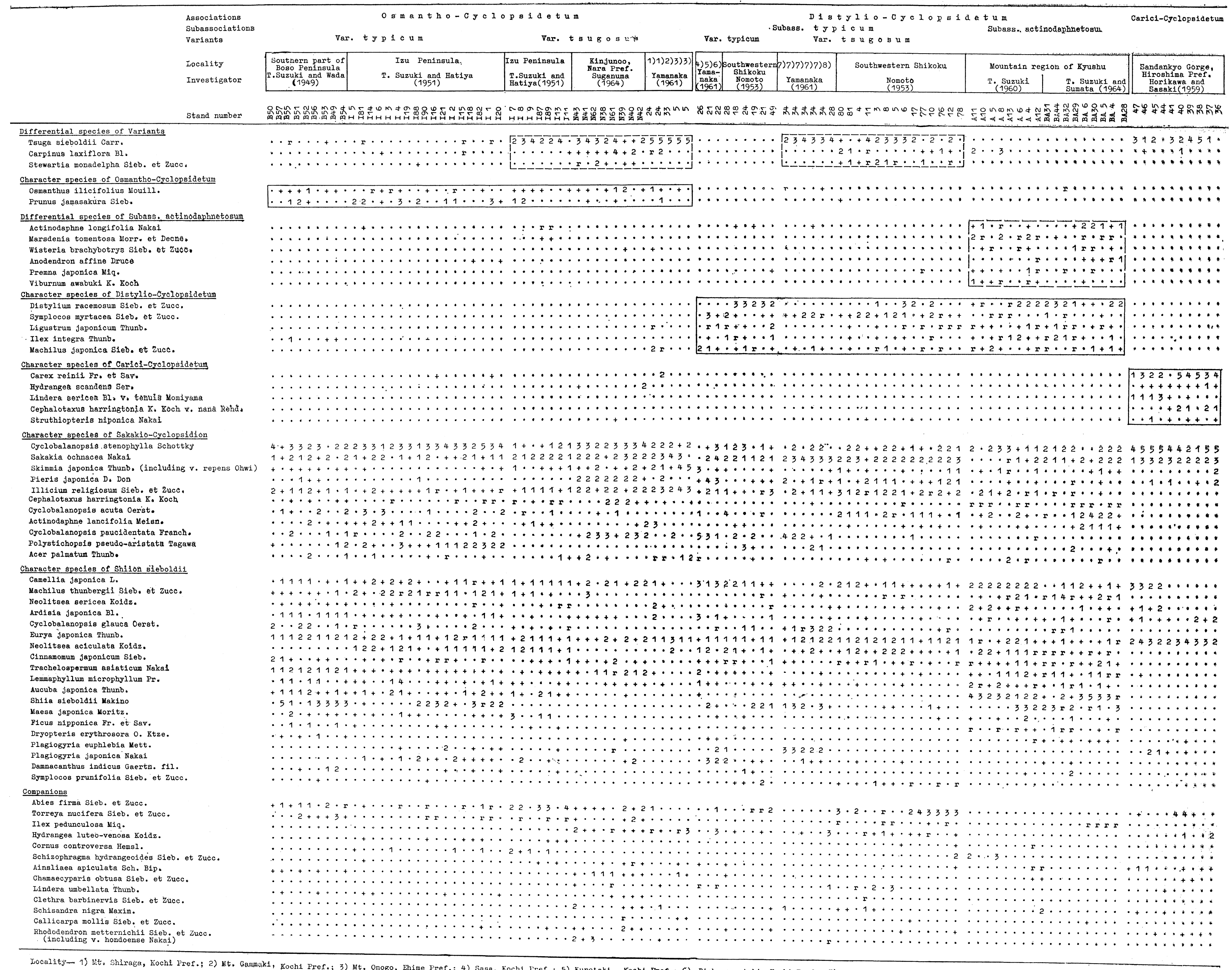


weight was laid upon the dominance and the vitality in Japan than in Europe. In making the unified table of the old Sakakieto-Cyclobalanopsidetum stenophyllae, the present writer, following the modern tradition of European phytosociologists, evaluated the existence of the species in the respective community above all other criteria (dominance or vitality).

In composing the revised table, some corrections and unifications were made by the writer. The symbol " $r$ " in the table represents a small quantity of young individuals, which do not yet reach the height of their proper layers.

Y. Sasaki ${ }^{25)}$, who has recently made a monographic study of the Japanese beech forest of Southwestern Honshu, followed the rule proposed by Meijer Drees. The cord allows the bidimensional nomenclature below the association rank. After this cord, the subassociation must be an ecological and the variant a geographical subdivision of association. But the writer follows the traditional system as is shown by Braun-Blanquet ${ }^{26)}$ and Ellenberg ${ }^{27}$.

In the systematization of vegetational units, Latin names and priority system based upon the international agreement are no doubt desirable, but the priority system when adopted too strict, brings science often into complexity. By the agreement of the original authors, the writer has dared to give an adequate and possible short names to newly difined associations and subassociations. Thus the generic name Cyclobalanopsis were shortened to make the suballiance and association names, for example, as Sakakio-Cyclopsidion and Carici-Cyclopsidetum to avoid too long names.

\section{Documentation}

Sakakio-Cyclopsidion Suganuma et Suz.-Tok., new suballiance

Syn. Machileto-Shiietum sieboldi-Quercetosum stenophyllae Nakano ${ }^{11}$

Cyclobalanopsis stenophylla-Sakakia ochnacea association; Cyclobalanopsidetum sakakiosum stenophyllae Suz.-Tok. et Wada ${ }^{12)}$

Sakakieto-Cyclobalanopsidetum stenophyllae Suz.-Tok. ${ }^{1,14,15,17)}$

Character Species: Cyclobalanopsis stenophylla Schottky, Sakakia ochnacea Nakai, Skimmia japonica Thunb. (including var. repens Ohwi), Pieris japonica D. Don, Illicium religiosum Sieb. et Zucc., Cephalotaxus harringtonia K. Koch, Cyclobalanopsis acuta Oerst., Actinodaphne lancifolia Meisn., Cyclobalanopsis paucidentata Franch., Polystichopsis pseudo-aristata Tagawa and Acer palmatum Thunb.

Habitat: Rather foggy region at the upper range of the Shiion sieboldi, or on mountain slopes along the valley with topographically restricted illumination in districts with drier season. On shale and sandstone of tertiary formation, andesite, granite or other igneous rock, but seldom on quaternary deposits.

Range: From the Pacific Coast of the Tohoku District (northern limit in Marumori, Miyagi Prefecture ${ }^{28)}$ ) southwestward to Central Kyushu. San'in District in the region facing to the Japan Sea (Fig. 1). Vertically from the hill belt up to its higher limit.

1. Ass. Osmantho-Cyclopsidetum Suganuma, new rank (Table 1, Fig. 1)

Syn. Sakakieto-Cyclobalanopsidetum osmanthetosum Suganuma ${ }^{21}$

Cyclobalanopsis paucidentata subassociation of Cyclobalanopsis stenophylla-Sakakia ochnacea association Suz.-Tok. et Hatiya ${ }^{13)}$

Sakakieto-Cyclobalanopsidetum paucidentetosum Suz.-Tok. ${ }^{1)}$ 


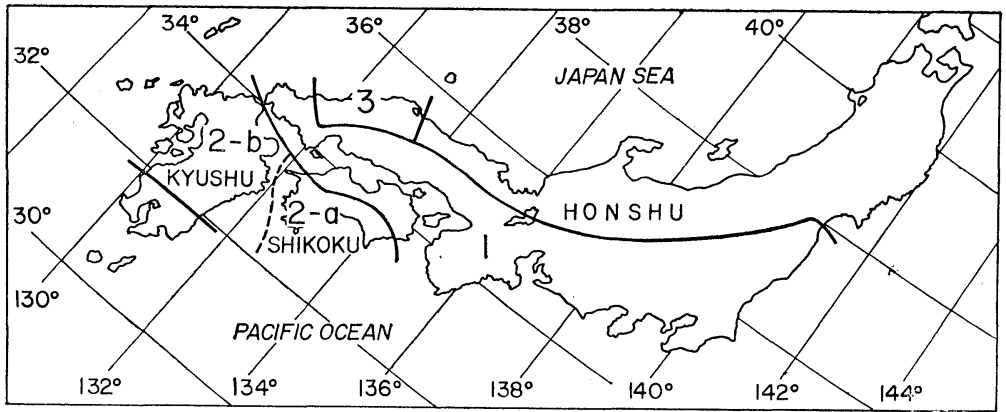

Fig. 1. A map showing the sphere of the suballiance Sakakio-Cyclopsidion.

1: Osmantho-Cyclopsidetum,

2: Distylio-Cyclopsidetum,

-a: Subass. typicum,

-b: Subass. actinodaphnetosum,

3: Carici-Cyclopsidetum.

Character Species: Osmanthus ilicifolius Mouill. and Prunus jamasakura Sieb.

Var. typicum Suganuma, new position

Locality: Southern part of the Boso Peninsula, Chiba Prefecture ${ }^{12}$ ) and the Izu Peninsula, Shizuoka Prefecture ${ }^{13)}$

Habitat: Windward side to the dominant wind in winter. Topographically re. stricted illumination. Somewhat humid air condition. Seldom underlain by mycorrhiza horizon.

Syndynamic State: Climax of the hill belt except the lower part.

Var. tsugosum Suganuma ${ }^{21}$

Syn. Tsuga sieboldii subassociation of Cyclobalanopsis stenophylla-Sakakia ochnacea association Suz.-Tok. et Hatiya ${ }^{13)}$ 1. c.

Sakakieto-Cyclobalanopsidetum tsugetosum Suz.-Tok. ${ }^{1)}$

Differential Species: Tsuga sieboldii Carr., Carpinus laxiflora B1. and Stewartia monadelpha Sieb. et Zucc.

Locality: Izu Peninsula, Shizuoka Prefecture ${ }^{13)}$; Kinjunoo, Nara Prefecture ${ }^{21)}$; Mts. Shiraga and Gammaki, Kochi Prefecture ${ }^{20)}$ and Mt. Omogo, Ehime Prefecture ${ }^{20}$

Habitat: Sunny slope on the leeward side to the winter monsoon. Somewhat heavy frost in autumn, but without much snow-accumulation. Mycorrhiza layers are often found below the surface.

Syndynamic State: Theoretically subclimax, but remain permanent in the upper part of the hill belt.

2. Ass. Distylio-Cylopsidetum Nomoto et Suganuma, new rank (Table 1, Fig. 1)

Syn. Sakakieto-Cyclobalanopsidetum distylietosum Nomoto $^{16)}$; Suz.-Tok. ${ }^{19)}$; Suz.-Tok. et Sumata ${ }^{6}$

Character Species: Distylium racemosum Sieb. et Zucc., Symplocos myrtacea Sieb. et Zucc., Ligustrum japonicum Thunb., Ilex integra Thunb. and Machilus japonica Sieb. et Zucc.

The subassociation distylietosum was established by Nomoto, opposing to the other subassociation tsugetosum, but the association is enlarged by the writer to contain Nomoto's subassociation tsugetosum. 
2-a. Subass. typicum Suganuma, new position

This subassociation was opposed to the next subassociation actinodaphnetosum by the distinct differential group in this association. The typical subassociation was found mainly in Southwestern Shikoku, which is divided topographically into the following two variants.

Var. typicum Suganuma, new position

Locality: Southwestern Shikoku ${ }^{16)}$ and Sasa, Kurotaki and Bishamonnotaki, Kochi Prefecture ${ }^{20}$

Habitat: Sunny slope, with somewhat moist air condition.

Syndynamic State: Climax of the hill belt, but usually lower than the next variant.

Var. tsugosum Suganuma, new rank

Syn. Sakakieto-Cyclobalanopsidetum tsugetosum (non Suz.-Tok. ${ }^{1}$ ) Nomoto ${ }^{16}$

Sakakieto-Cyclobalanopsidetum rhodoretosum Yamanaka ${ }^{20)}$

Differential Species: Tsuga sieboldii Carr., Carpinus laxiflora Bl. and Stewartia monadelpha Sieb. et Zucc.

Locality: Southwestern Shikoku ${ }^{16)}$ and Agura and Higashigawa, Kochi Prefecture ${ }^{20)}$

Habitat: Windward slope, facing to the winter monsoon, often neighboring upward to the beech forest directly. More snowy, when compared with the above variant.

Syndynamic State: Climax of the hill belt of those districts, where beech climax protrudes into the low altitude.

2-b. Subass. actinodaphnetosum Suganuma, new subass.

Syn. Skimmieto-Cyclobalanopsidetum acutae Sumata et al. ${ }^{22)}$; Suz.-Tok. et Sumata ${ }^{6}$.

Sakakieto-Cyclobalanopsidetum distylieto um Nomoto, pro parte, auct. Suz.-Tok. ${ }^{19}$.

Differential Species: Actinodaphne longifolia Nakai, Marsdenia tomentosa Morr, et Decne., Wisteria brachybotrys Sieb. et Zucc., Anodendron affine Druce, Premna. japonica Miq. and Viburnum awabuki K. Koch

Locality: Mt. Kitamuki, Kumamoto Prefecture ${ }^{19)}$ and Mts. Ondake and Hutago and Hashirimizu-Kannon, Ooita Prefecture ${ }^{6)}$

Habitat: Nearly same as in Var. typicum of the subassociation typicum, but often moister in some stands (those belonging to Skimmieto-Cyclobalanopsidetum acutae). Attaining to the lower limit of the Illicieto-Abietum cyclobalanopsidetosum.

Syndynamic State: Climax in the upper part of the hill belt in Central and Eastern Kyushu.

3. Ass. Carici-Cyclopsidetum Sasaki et Suganuma, new ass. (Table 1, Fig. 1)

Syn. Sakakieto-Cyclobalanopsidetum stenophyllae (non Suz.-Tok. et Hatiya ${ }^{13)}$ ). Horikawa et Sasaki ${ }^{18)}$

Character Species: Carex reinii Fr. et Sav., Hydrangea scandens Ser., Lindera sericea Bl. var. tenuis Momiyama, Cephalotaxus harringtonia $\mathrm{K}$. Koch var. nana Rehd. and Struthiopteris niponica Nakai

Locality: Sandankyo Gorge, Hiroshima Prefecture ${ }^{18)}$

Habitat: Steep slope of gorge with topographically restricted illumination and shallow soil.

Syndynamic State: Subclimax in the periphery region of the suballiance.

\section{Discussion}

1. Character species of the alliance

The character species of the alliance, Shiion sieboldii are for the most part 
subtrees, like Camellia japonica, Neolitsea sericea, N. aciculata, Eurya japonica and Cinnamomum japonicum; shrubs, like Aucuba japonica and Maesa japonica; fern of the forest-floor, like Dryopteris erythrosora, Plagiogyria euphlebia and P. japorica etc. Moreover there come the character species of other associations in minor presence, as Machilus thunbergii, Shiia sieboldii, Cyclobalanopsis glauca. It is a noteworthy fact, though already accentuated by $\mathrm{T}$. Suzuki ${ }^{29-31)}$, they belong to a restricted number of families. Arboreal flora is composed mainly of Fagaceae, Lauraceae and Camelliaceae. The herbaceous flora of the forest floor is composed of Polypodiaceae. Some arboreous species are found in the subtree, shrub and herb layers of the forest. This special feature remains not only in the total flora but also in the alliance characteristics.

2. Suballiance Sakakio-cyclopsidion

The original association of the Sakakieto-Cyclobalanopsidetum stenophyllae, although it has been adopted to the distant localities by different authors, remains quite compact by the following common species, Cyclobalanopsis stenophylla, Sakakia ochnacea and other species. They occur transgressively in other communities, but their characteristic combination builds up a nucleus of the original association. In spite of the unity, this compact community shows remarkable regional differences on the other hand. This is the reason why the original association shall be put in the rank of suballiance.

3. Carici-Cyclopsidetum

On inspecting the synthetical table, one can never overlook the absence of number of alliance and suballiance characteristics in the stands of the Sandankyo Gorge. The original authors, Horikawa and Sasaki ${ }^{18}$ ) have registered this and called the phenomenon reasonably the "simplification of association". The simplification is also detected by T. Suzuki and Mori ${ }^{32}$ in the remaining stands of the Shiion sieboldii in the Rokko Mountains. The simplification is accompanied by the occurrence of a number of species, whose original habitats are rather in the cooler climatic or forest region. In this periphery district, an association can be naturally characterized by the negative exclusiveness. The absence of the character species of the other two associations, and the common species of these two will be good bases to recognize this as an independent association locality in the periphery of the area of suballiance.

4. Osmantho-Cyclopsidetum

From the writer's unified table, a distinct floristic contrast is detected between the Eastern and Southwestern halves of the table. The stands of the Eastern and Central Japan are characterized by Osmanthus ilicifolius and Prunus jamasakura, while the Southwestern by Distylium racemosum, Symplocos myrtacea and others.

T. Suzuki and Hatiya ${ }^{13)}$ and also Nomoto ${ }^{16}$ laid greater stress upon the dominance of coniferous trees, Abies firma and Tsuga sieboldii. It might be natural, when one confines the study in more restricted area. From the unified table, however, the contrast between Osmanthus ilicifolius group and that of Distylium racemosum is more evident than the difference between the group with coniferous trees and the pure broad-leaved evergreen forest stands. The latter is rather an ecological grouping, while the former a geographical. In cases of such a overlapping grouping, the bidimensional system will be appropriately adopted as proposed by Meijer Drees and by Y. Sasaki. The writer will discuss it latter again.

Suganuma ${ }^{21}$ has established the subassociation osmanthetosum in the SakakietoCyclobalanopsidetum stenophyllae in the original sense, and abandoned the old name 
paucidentetosum, though valid from the formal priority. Now, the new name of association is appropriate to its entity, and has no difficulty in the nomenclatural custom, too.

\section{Distylio-Cyclopsidetum}

Because the former two have been explained of the necessity to be recognized in the association rank, the third, the old subassociation distylietosum with more distinct character species will naturally be an independent association.

This association can be divided into two parts. The first is the subassociation typicum, which is composed of two variants. One is the variant tsugosum, which is continuous to the same variant of the Osmantho-Cyclopsidetum, and the other is the variant typicum, which lacks neither of the differential group of the tsugosum. And the second is the subassociation actinodaphnetosum.

Yamanaka $^{20)}$ investigated the forest community in the whole area of Shikoku and recognized Sakakieto-Cyclobalanopsidetum stenophyllae as a member of Abies firma and Tsuga sieboldii forest, and he pointed out that the pure Cyclobalanopsis forest was very rare if not absent there, because those forests are generally accompanied with Abies firma and Tsuga sieboldii with abundant Symplocos myrtacea. He had some questions about the prevalence of Cyclobalanopsis forest in Shikoku, but was inclined to characterize the forest there as the Sakakieto-Cyclobalanopsidetum stenophyllae. Also he distinguished some topographically clear stands as the subassociation rhodoretosum. Table 1 of the present article is composed according to Yamanaka except for the southwestern part, where Nomoto made an earlier survey. Hence the occurrence of the subassociation rhodoretosum is not confirmed in this table. Nevertheless, the composition of differential species in the subassociation rhodoretosum strongly suggests that this subassociation in Shikoku can be distinguished at the systematic rank of the Rhododendron metternichii facies as well as that the Kinjunoo natural forest which appears in the central part of the Kii Peninsula and is established as an analogous facies in the Osmantho-Cyclopsidetum (as the subassociation osmanthetosum ${ }^{21)}$ ).

In Kyushu, T. Suzuki ${ }^{19)}$ has determined the Cyclobalanopsis forest dominated by Shiia sieboldii to the Shiia sieboldii facies of the Sakakieto-Cyclobalanopsidetum. distylietosum described by Nomoto from Southwestern Shikoku.

And Skimmieto-Cyclobalanopsidetum acutae was orally published by Sumata $e t$ $a .^{22)}$ as a mossy forest of Cyclobalanopsis-type, and it was later authorized by the table $^{6}$. Although some differences are detectable in the local table, it is difficult to define this association from the unified table, so the present writer reduced it into synonymy.

6. Bidimensional system

The writer follows here the traditional way shown by Braun-Blanquet or $\mathrm{H}$. Ellenberg and does not adopt the bidimensional system, as Y. Sasaki did of the beech forest of Western Honshu, although there exist a overlapping group like the tsugosum, and the parallel group like the Rhododendron metternichii facies, which will be better treated by the bidimensional system.

But the subassociation actinodaphnetosum of the Distylio-Cyclopsidetum and the Carici-Cyclopsidetum when considered as a lower unit of an association are very difficult to determine whether ecological or geographical.

Bidimensional system implied an excellent idea, but we fear it should induce science into complexity, when it is combined of proper names of plant communities. 
7. Simplification of floristic composition

Already Horikawa and Sasaki ${ }^{18}$ have referred to the simplification of the floristic composition of a plant community in the periphery region. This phenomenon is detectable over the whole table synthesized by the writer.

The southernmost association Distylio-Cyclopsidetum has two subassociations, and the southernmost subassociation actinodaphnetosum is the richest of the number of differential species. When one compares the character species groups between the two associations, the Osmantho-Cyclopsidetum is not only poor in the number of differential species, but Prunus jamasakura is a deciduous tree, which is ecologically rather a stranger in a broad-leaved evergreen forest. The gradient of simplification attained the extremity in the Carici-Cyclopsidetum, as mentioned above.

8. Variant tsugosum

The variant tsugosum attains to the Carici-Cyclopsidetum, and the differential species of this variant are also ecological strangers or destructors. The localities of these ecologically rather heterogenous forests are found on the leeside slopes of mountains opposing the dominant wind of the winter monsoon, and concentrate the widest part of the Japanese Archipelago, where the influence of the oceanic air mass becomes weaker.

\section{Acknowledgment}

The writer wishes to express his sincere thanks to Prof. T. Suzuki of Ooita University for helpful suggestions and careful reading of the manuscript before publication.

Thanks are also due to Dr. T. Yamanaka of Kochi University, Dr. N. Nomoto of Ibaragi University and Dr. Y. Sasaki of Hiroshima University as well as Prof. T. Suzuki for kindly making their original data available to compose the synthetic table of the associations all over the land of Japan.

\section{Summary}

The writer has revised the Cyclobalanopsis-type forest in Japan by one comprehensive table involving all the data acquainted till now, and in particular, the phytosociological systematization of Sakakieto-Cyclobalanopsidetum stenophyllae Suz.Tok. 1952 was critically studied.

As a result of the investigation, it was recognized that the old Sakakieto-Cyclobalanopsidetum stenophyllae consisted of three associations. And these have been unified into a new suballiance Sakakio-Cyclopsidion, as follows.

Suball. Sakakio-Cyclopsidion Suganuma et Suz.-Tok., new suball.

1. Ass. Osmantho-Cyclopsidetum Suganuma, new rank

Var. typicum, new position

Var. tsugosum Suganuma 1964

2. Ass. Distylio-Cyclopsidetum Nomoto et Suganuma, new rank

-a. Subass. typicum Suganuma, new position

Var. typicum, new position

Var. tsugosum Suganuma, new rank

-b. Subass. actinodaphnetosum Suganuma, new subass.

3. Ass. Carici-Cyclopsidetum Sasaki et Suganuma, new ass. 


\section{References}

1) Suzuki, T., The Forest Climaxes in East Asia (Kakin-Syoin, Tokyo, 1952). 2) — Vegetatio 5-6: 361 (1954). 3) —, Bull. Tokyo Univ. Forests 41: 57 (1951). 4) Sasaki, Y., Bull. Biol. Soc. Hiroshima Univ. 8: 16 (1958). 5) Yamanaka, T., Res. Rep. Kochi Univ. 4(2): 1 (1955). 6) Suzuki, T. and Sumata, H., Res. Bull. Oita Univ. (Nat. Sci.) 2(4): 59 (1964). 7) - Shinrin-Ricchi 2(1): 1 (1960). 8) Honda, S., On the Forest Vegetation Zones in Japan (Miura-Shoten, Tokyo, 1900). 9) Tanaka, Z., Vegetation Zones of Japan (Tokyo, 1887). 10) Suzuki, T., Chiri 6(9): 22 (1961). 11) Nakano, H., Ann. Phytoecol. 3: 1 (1943). 12) Suzuki, T. and Wada, K., Bull. Tokyo Univ. Forests 37: 115 (1949). 13) — and Hatiya, K., ibid. 39: 145 (1951). 14) —, Jap. Journ. Bot. 14: 1 (1953). 15) —, Midori 2(4): 12 (1950). 16) Nomoto, N., Bull. Tokyo Univ. Forests 45: 121 (1953). 17) Suzuki, T., Proceedings of the 25th Annual Meeting of the Botanical Society of Japan (1955). 18) Horikawa, Y. and Sasaki, Y., Sci. Res. the Sandankyo Gorge and Yawata Highland 85 (The Educational Committee of Hiroshima Prefecture, Hiroshima, 1959). 19) Suzuki, T., Report of the 5th Meeting of Kyushu Branch of the Ecological Society of Japan (1960). 20) Yamanaka, T., Res. Rep. Kochi Univ. 10: 19 (1961). 21) Suganuma, T., Hikobia 4: 103 (1964). 22) Sumata, H., Sato, Z., Hutamura, S. and Suzuki, T., Report of the 1st Meeting of Kyushu Branch of the Ecological Society of Japan (1956). 23) Usui, H. and Kashiwa, H., Transactions of the 72nd Meeting of the Japanese Forestry Society (1962). 24) Suzuki, T., Sato, Z. und Sumata, H., Pflanzengesellschaften des Berges Takasaki, Ooita, Japan, besiedelt von wilden Affenherden (Ooita, 1964). 25) Sasaki, Y., Jour. Sci. Hiroshima Univ. Ser. B. Div. 2 10: 1(1964). 26) BraunBlanquet, J., Pflanzensoziologie, Grundzüge der Vegetationskunde (Springer, Wien, 1951). 27) Ellenberg, H., Grundlagen der Vegetationsgliederung I. Aufgaben und Methoden der Vegetationskunde, Einführung in die Phytologie von H. Walter. IV-I. (Eugen Ulmer, Stuttgart, 1956). 28) Murai, S., Aomori-Rinyu, Nos. 25-29 (1950-51). 29) Suzuki, T., Jap. J. Ecol. 4: 7 (1954). 30) —- Acta Phytotax. Geobot. 20: 84 (1962). 31) —, Res. Bull. Oita Univ. (Nat. Sci.) 2(2): 23 (1961). 32) - and Mori, H., ibid. 1(6): 29 (1957).

\section{摘 要}

菅沼孝之：ウラジロガシーサカキ群集について

わが国の暖带林植生の中核をなすスダシイ群団を構成する一員であるカシ型森林について, 現在まで沉 発表された原著者の群集組成表の原表，ならびに野帳の資料をもとにして全国統一組成表を作成し，特に ウラジロガシ一サカキ群集について群集の体系を考察した。 その結果, 本群集は 3 つ標徵種群をもつこ とが明らかとなり，3群集に分忛た。な扮，近縁のアカガシーミヤマシキミ群集はコケ林としての性格を もつことが知られているが，独自の標徴種群をもたず，新 3 群集の 1 つであるウラジロガシーイス群集に ふくめられることが明らかになった，新たに分類された 3 群集は，隣接するカシ型の森林の組成と異なる 要素をもつので, これらをウラジロガシーサカキ亜群団に総括した.

ウラジロガシーサカキ亜群団（異名：タブーシイ群叢一ウラジロガシ下群叢； ウラジロガシ一サカキ群 集)は次のように構成される。

1. ウラジロガシーヒイラギ群集（異名：ヒイラギ亜群集；ツクバネガシ亜群集） 標準変群集 ツガ変群集（異名： ツガ亜群集）

2. ウラジロガシーイス群集（異名：イス亜群集）

a. 標準亜群集

標準変群集

ツガ変群集（異名：ツガ亜群集）

b. バリバリノキ亜群集（異名：アカガシーミヤマシキミ群集）

3. ウラジロガシーコカンスグ群集（異名：ウラジロガシ一サカキ群集，一部） 群集扰よび亜群集の領域は第 1 図に示す通りである. (奈良女子大学理学部植物学教室) 